\title{
THE ROLE OF HOSPITAL MANAGEMENT TO ENHANCE NURSING JOB SATISFACTION
}

\author{
Tantri Arini $^{1 *}$, I Gede Juanamasta ${ }^{2}$ \\ ${ }^{1}$ STIKes Bhakti Husada Mulia Madiun \\ ${ }^{2}$ STIKes Wira Medika Bali \\ Email*: ar.rhein.arini@gmail.com
}

\begin{abstract}
Introduction: Hospital management must strive to create a work environment that can build nurse autonomy at work empowerment carried out by management in the workplace will be a crucial way to support nurse autonomy so that nursing job satisfaction can be created. The study aimed to identify the relationship between the role of hospital management with nurse job satisfaction. Methods: This research was conducted using a cross-sectional design, with a correlation analytic study design, and the sampling technique used was simple random sampling. The total samples in this study were 41 people. Data collection on hospital management roles was collected using the CWEQ II (Condition for Work Effectiveness-II) questionnaire, while nurse job satisfaction used MMSS (The McCloskey/Mueller Satisfaction Scale). The data analyzed by Pearson Rho. Results: Based on the results of the study obtained, the majority of respondents aged 21-40 years (63.4\%), most respondents had vocational education background (73.2\%), and most respondents had work experience > 10 years $(58.5 \%)$. Based on the results of the Pearson correlation test obtained p-value < 0.05 (0.005), so it means that there was a relationship between the role of hospital management with nursing job satisfaction. Conclusions: Nurse managers can consider structural empowerment in the work environment for their employees. The quality of the nurse's work environment at the work unit level is not only important to improve the quality of service to patients, but also has an important role in improving the welfare of individual nurses themselves.
\end{abstract}

Keywords: job satisfaction; nurse administrators; workplace

\section{INTRODUCTION}

Nurses are health service agents who play a structural role and carry the mission for a better organizational change. So in line with this, nurses become one of the keys or determining factors in the health services of an organization in all health care services. If nurses are considered not right, then the services in an organization are also perceived poorly by users of health services (Teixeira $\&$ Barbieri-Figueiredo, 2015). As found in research conducted on nurses in rural areas in Jordan, states that the level of nurse satisfaction is at the borderline (AbuAlRub, El-Jardali, Jamal, \& Al-Rub, 2016). The satisfaction of nurses in intensive care installations in the majority of Chinese regions is also still in the moderate category $3.41(2.34 \leq$ mean $\leq 3.66$ moderate level of satisfaction) (Tarcan, Hikmet, Schooley, Top, \& Tarcan, 2017), while from several studies in Indonesia, nurses' job satisfaction in Surabaya is still at a low level of 67.9\% (Cholilah \& Paskarini, 2013), while the job satisfaction of nurses in Blitar was mostly also at the level of moderate level as much as
68.9\% (Ahsan \& Pradyanti, 2015). It can be concluded that nurse job satisfaction in some places majority still at a moderate level.

Nurse satisfaction with the work environment is associated with psychological empowerment and structural empowerment in the workplace (Laschinger, Nosko, Wilk, \& Finegan, 2014). Structural empowerment in the workplace will increase nurse satisfaction, nurse self-efficacy, productivity, and effectiveness of nurse work (Teixeira \& Barbieri-Figueiredo, 2015). Empowerment means to support nurse autonomy so that that nurse job satisfaction can be created. The managerial level of nursing must be conditioning a work environment that can provide access to information, provide necessary resources, provide support to employees, and provide opportunities for employees to grow and develop. These are ways to carry out structural empowerment that can encourage the ability of an employee in order to complete work in his workplace (Laschinger, Finegan, \& Wilk, 2011). 
The study aimed to analyze the relationship between the role of hospital management with nurse job satisfaction. One of the solutions to problems related to nursing satisfaction is that the majority are still at a moderate level in this research by looking at the role of hospital management through structural empowerment carried out on its employees. It is expected that the level of hospital management can pay attention to various sectors by empowering their employees.

\section{METHODS}

This research was conducted using a cross-sectional design, with correlation analytic research design. This study used simple random sampling. This study was done in one regional hospital in East Java, after get permission from the Hospital Institutional Review Board No.445/3.162/303/2017. The population in this study were nurses in the ward with a number of 57 people. The number of samples was calculated so that 41 people were obtained whereby inclusion criteria were minimum one year experienced, and exclusion criteria were nurse grantee and maternity leave.

The data was collected by using the CWEQ II (Condition for Work EffectivenessII) structural empowerment questionnaire (Laschinger, Finegan, Shamian, \& Wilk, 2001). The instrument consists of 19 question items that measure structural empowerment in the workplace, which are described by formal forces, informal forces, information, support, access to resources, and opportunities. The research items consisted of 5 points on a Likert scale, with ranging score 19 to 95 . The reliability test results in this instrument are 0.91, and validity is 0.99 (Bernardino, Dyniewicz, Carvalho, Kalinowski, \& Bonat, 2013).

Nurse job satisfaction used MMSS (The McCloskey / Mueller Satisfaction Scale) (Tourangeau, Hall, Doran, \& Petch, 2006). This instrument was developed by the department of

Table 1. Distribution of frequencies by age

\begin{tabular}{lll}
\hline Variables & Frequency & Percentage \\
\hline Age & & \\
\hline 21-40 years old & 26 & 63.4 \\
\hline >40 years old & 15 & 36.6 \\
\hline Education background & & \\
\hline$\quad$ Vocational & 30 & 73.2 \\
\hline Bachelor & 11 & 26.8 \\
\hline Work experience & & \\
\hline 1-3 years & 3 & 7.3 \\
\hline 3-5 years & 6 & 14.6 \\
\hline 5-10 years & 8 & 19.5 \\
\hline$>10$ years & 24 & 58.5 \\
\hline
\end{tabular}

Table 2. Analysis of variable

\begin{tabular}{lllllllll}
\hline Variable & N & Mean & Median & SD & Min & Max & P-value & r \\
\hline $\begin{array}{l}\text { Hospital } \\
\text { management's } \\
\text { role }\end{array}$ & 41 & 46.78 & 48.00 & 6.00 & 30.00 & 57.00 & & \\
\cline { 1 - 1 } & & & & & & & & \\
$\begin{array}{l}\text { Nurses job } \\
\text { satisfaction }\end{array}$ & 41 & 88.12 & 89.00 & 7.07 & 68.00 & 105.00 & & 0.431 \\
\hline
\end{tabular}


nursing at the University of Iowa. There are eight factors which are divided into three aspects: 1) security rewards consisting of external rewards, service schedules and balance between family and work, 2) social rewards consisting of relationships with colleagues and opportunities to interact in the work environment, 3) psychological rewards which include the opportunity to develop professionalism, control and responsibility and the appreciation and praise received. Measurements were using a Likert scale from number 1 (very dissatisfied) to number 5 (very satisfied), with ranging score 31 to 155 . The results of research from O'Neal (2012) states that the results of the Cronbach alpha reliability test from MMSS are around $0.61-0.89$, which means that the coefficient value> 0.6 means the reliable instrument items are used in the study.

Respondents in this study have explained the purpose of the benefits and ways of collecting data to be carried out in the study. After the respondent is willing, the respondent is asked to fill in the informed research consent and fill out the questionnaire. Based on the research objective to analysis the relationship between the role of hospital management and nurse job satisfaction, this study used the Pearson Rho statistic test, with the software of SPSS version 22 (Hidayat, 2017).

\section{RESULTS}

Based on the table 1, it can be concluded that the majority of respondents aged 21-40 years which is 26 respondents $(63.4 \%)$, they also dominated vocational education which is 30 respondents $(73.2 \%)$, and their work experience mostly more than ten years which is 24 respondents $(58.5 \%)$.

Based on the table 2, the mean of the hospital management role is 46.78 , and nurse's job satisfaction 89 . It can be concluded that the p-value $<0.05(0.005)$ so that there was a relationship between hospital management's role with nurse job satisfaction. The strength of the correlation between the two variables was at a moderate level (0.431).

\section{DISCUSSIONS}

The role of hospital management can be done through structural empowerment carried out by superiors or the level of hospital management to its staff. Empowerment is defined as the acceptance of power (as a result of working conditions offered by the organization) so that individuals can complete their work effectively (Laschinger, Gilbert, Smith, \& Leslie, 2010). An employee will feel empowered if the employee has access to the organization, gets the information needed, and gets support to make a decision. The process will affect the process of services provided to patients, improve the quality of services, and improve patient outcomes (Armellino, Quinn Griffin, \& Fitzpatrick, 2010). The application of structural empowerment in the workplace requires the attention of nursing managers, especially to pay attention to aspects of structural empowerment for the development of personal resources owned by each nurse. Empowered nurses will feel that they are cared for by the managerial and become an asset of valuable resources in the future (Boamah \& Laschinger, 2015).

Nurse managers may consider structural empowerment in the work environment for their employees (Armellino et al., 2010). An employee who has access to information, support, resources, and had opportunities in his work, then the employee will feel empowered by his abilities so that employees can complete their work meaningfully (Guo et al., 2016). That will increase employee's or nurse staff's trust in the nurse's manager. Besides, they will feel comfortable and safe when they work, and their performance will increase indirectly.

A positive relationship between empowerment at work and nurse job satisfaction has been the end result of many studies, including research from Regan, Laschinger, \& Wong (2016). In addition, according to Bawafaa, Wong, \& Laschinger (2015), structural empowerment has a direct effect on job satisfaction of nurses and the 
quality of services provided by nurses. Laschinger, Nosko, Wilk, \& Finegan (2014) in a study states that the quality of the nurse's work environment at the work unit level is not only important to improve quality service to patients, but also has an important role in improving the welfare of individual nurses themselves. Structural empowerment in the workplace will increase nurse satisfaction, nurse self-efficacy, productivity and effectiveness of nurse work (Teixeira \& Barbieri-Figueiredo, 2015). Nurse managers can facilitate positive outcomes by creating a work environment that empowers their staff. Structural empowerment provides an opportunity, full access and support from the managerial staff for nurses, to carry out professional development of the nursing staff.

The limitations of this study, the researcher, didn't measure other factors can influence job satisfaction, such as leadership or managerial factor. Moreover, the researcher ignores the confounding variables, such as individual personal conditions. Thus, another study should control confounding variables or modify the questionnaire.

\section{CONCLUSIONS}

Nurses will feel the attention of management related to their development to create nurse job satisfaction. In addition, structural empowerment guides so that management always actively disseminates the latest issues related to health services and goals to be achieved by health care organizations, so that nursing staff know the direction of the management, and they can feel satisfied with their working environment. That will increase performance in the clinical setting because nurses feel cared for by hospital management.

\section{REFERENCES}

AbuAlRub, R., El-Jardali, F., Jamal, D., \& AlRub, N. A. (2016). Exploring the relationship between work environment, job satisfaction, and intent to stay of Jordanian nurses in underserved areas. Applied Nursing Research, 31, 19-23.
Ahsan, A., \& Pradyanti, A. Y. C. (2015). Job Stress and Job Satisfaction Among Nurses in Mardi Waluyo Hospital Blitar. Jurnal Ners, 10(2), 318-323.

Armellino, D., Quinn Griffin, M. T., \& Fitzpatrick, J. J. (2010). Structural empowerment and patient safety culture among registered nurses working in adult critical care units. Journal of Nursing Management, 18(7), 796-803

Bawafaa, E., Wong, C. A., \& Laschinger, H. (2015). The influence of resonant leadership on the structural empowerment and job satisfaction of registered nurses. Journal of Research in Nursing, 20(7), 610-622.

Bernardino, E., Dyniewicz, A. M., Carvalho, K. L. B., Kalinowski, L. C., \& Bonat, W. H. (2013). Transcultural adaptation and validation of the Conditions of Work Effectiveness-Questionnaire-II instrument. Revista Latino-Americana de Enfermagem, 21(5), 1112-1118.

Boamah, S., \& Laschinger, H. (2015). Engaging new nurses: the role of psychological capital and workplace empowerment. Journal of Research in Nursing, 20(4), 265-277.

Cholilah, N., \& Paskarini, I. (2013). Hubungan motivasi kerja dengan prestasi kerja dan kepuasan kerja perawat unit IGD dan ICU di RS PHC Surabaya. The Indonesian Journal of Occupational Safety And Health, 2(2), 162-166.

Guo, J., Chen, J., Fu, J., Ge, X., Chen, M., \& Liu, Y. (2016). Structural empowerment, job stress and burnout of nurses in China. Applied Nursing Research, 31, 41-45.

Hidayat, A. A. (2017). Metodologi Penelitian Keperawatan dan Kesehatan. Jakarta: Salemba Medika, 88.

Laschinger, H. K. S., Finegan, J., Shamian, J., \& Wilk, P. (2001). Impact of structural and psychological empowerment on job strain in nursing work settings: expanding Kanter's model. JONA: The Journal of Nursing Administration, 31(5), 260-272.

Laschinger, H. K. S., Finegan, J., \& Wilk, P. 
(2011). Situational and dispositional influences on nurses' workplace wellbeing: The role of empowering unit leadership. Nursing Research, 60(2), 124-131.

Laschinger, H. K. S., Gilbert, S., Smith, L. M., \& Leslie, K. (2010). Towards a comprehensive theory of nurse/patient empowerment: applying Kanter's empowerment theory to patient care. Journal of Nursing Management, 18(1), 4-13.

Laschinger, H. K. S., Nosko, A., Wilk, P., \& Finegan, J. (2014). Effects of unit empowerment and perceived support for professional nursing practice on unit effectiveness and individual nurse wellbeing: A time-lagged study. International Journal of Nursing Studies, 51(12), 16151623.

O'Neal, A. D. (2012). The Effects of Work Schedule Flexibility on Job Satisfaction of Telephone Advice Nurses.

Regan, S., Laschinger, H. K. S., \& Wong, C. A.
(2016). The influence of empowerment, authentic leadership, and professional practice environments on nurses' perceived interprofessional collaboration. Journal of Nursing Management, 24(1), E54-E61.

https://doi.org/doi:10.1111/jonm.12288

Tarcan, M., Hikmet, N., Schooley, B., Top, M., $\&$ Tarcan, G. Y. (2017). An analysis of the relationship between burnout, sociodemographic and workplace factors and job satisfaction among emergency department health professionals. Applied Nursing Research, 34, 40-47.

Teixeira, A. C., \& Barbieri-Figueiredo, M. C. (2015). Nursing empowerment and job satisfaction: an integrative review according the Structural Theory. Rev Enferm Ref [Internet], 4(6), 151-160.

Tourangeau, A. E., Hall, L. M., Doran, D. M., $\&$ Petch, T. (2006). Measurement of nurse job satisfaction using the McCloskey/Mueller Satisfaction Scale. Nursing Research, 55(2), 128-136. 